\title{
ZAMKNIECCIE MALEGO SEMINARIUM W KRAKOWIE PROWADZONEGO PRZEZ KSIĘŻY MISJONARZY ŚW. WINCENTEGO A PAULO W LATACH 1945-1962
}

Małe seminaria duchowne, zwane także niższymi, to owoc obrad Soboru Trydenckiego, który dostrzegał potrzebę odpowiedniego formowania duchowieństwa. W czasie dwudziestego trzeciego posiedzenia soborowego pochylono się nad nauką o sakramencie kapłaństwa ${ }^{1}$, wydano dekret o karności duchowieństwa ${ }^{2}$. W czasie tego posiedzenia zajęto się tematem odnowy kształcenia i formowania duchowieństwa. Opracowano dekret Cum adolescentium aetas - o seminariach duchownych $^{3}$, który został przyjęty 8 maja 1563 . Dekret ten zobowiązywał biskupów do tworzenia $w$ diecezjach zakładów naukowowychowawczych ku kształceniu nowych kapłanów. Miały być to ośrodki studiów i modlitwy. Rozpoczęły się też różne próby tworzenia seminariów duchownych. Takie placówki istniały już wcześniej w Hiszpanii i we Włoszech. We Francji, skąd wywodzi się Zgromadzenie Misji, pierwsze seminarium powstało w Reims (1567), po nim kolejne w Bordeaux i w Valence (1583), w Awinionie (1586) oraz w Tuluzie (1590). Niestety nie sprostały one postawionym przez sobór wymaganiom i zostały zamknięte. Dodatkowymi trudnościami były trwające ówcześnie wojny religijne ${ }^{4}$.

\section{Kształcenie duchowieństwa - realizacja charyzmatu}

Dobrze potrzebę kształcenia duchowieństwa widział założyciel Zgromadzenia Księży Misjonarzy, święty Wincenty a Paulo. Początkowo

${ }^{1}$ Conc. Trid., sess. XXIII, c. 1-4 de sacr. ordinis.

${ }^{2}$ Conc. Trid., sess. XXIII, c. 1-18 de ref.

${ }^{3}$ Conc. Trid., sess. XXIII, c. 18 de ref.

${ }^{4}$ L. M e z z a d r i, Wincenty a Paulo, miłosierdzie i świętość, Kraków 2010, s. 151.

„Nasza Przeszłość” t. 132: 2019, s. 317-335. 
zgromadzenie miało zająć się pomocą najuboższym i zadbaniem o życie duchowe mieszkańców wsi. Stąd pierwszym dziełem jego członków były tzw. misje ludowe (głoszone $\mathrm{z}$ wielkim poświęceniem), w czasie których przybliżane były podstawowe prawdy wiary oraz przygotowywano wiernych do spowiedzi, także generalnej, czyli z całego życia ${ }^{5}$. Wincentemu bardzo zależało, by dzieło misji świętych było podtrzymywane przez miejscowych księży. Niestety w tym czasie stan duchowieństwa pozostawiał wiele do życzenia. Sam św. Wincenty a Paulo mówił, że jest wielu kapłanów, którzy pogubili się w swoim życiu, choć nie można zapominać o tych, którzy pięknie i ofiarnie służą ${ }^{6}$. Wielu księży nie podejmowało duszpasterstwa w wyznaczonych parafiach, często byli też zgorszeniem dla wiernych. Problemem była ich rozwiązłość obyczajów, pijaństwo i pogoń za dobrami materialnymi ${ }^{7}$. Wielkim problemem była też ich niewiedza $\mathrm{w}$ dziedzinie liturgii ${ }^{8}$, a nawet nieznajomość formuły rozgrzeszenia ${ }^{9}$. Święty Wincenty wielokrotnie z przejęciem mówił o bólu, jaki sprawia mu fakt, że przygotowanie do kapłaństwa ma charakter przypadkowy, indywidualny, a studia na uniwersytetach nie dają podstaw dla pracy duszpasterskiej ${ }^{10}$.

Wincenty a Paulo miał świadomość w jakiej sytuacji znajdował się kler w ówczesnej Francji. Głosząc misje ludowe i rekolekcje na wsiach, odczytał, że Bóg powołuje go i jego zgromadzenie do podjęcia zadania zadbania o poziom wykształcenia duchowieństwa i odpowiedniego przygotowania go do pracy duszpasterskiej. Jako człowiek praktyczny, nie oddawał się tylko rozważaniom teoretycznym, ale pracował z księżmi i dla księży. Jego działalność przyczyniła się do wdrożenia obowiązku odbycia rekolekcji przez kandydatów przygotowujących się do przyjęcia święceń (od 1630 r.), do założenia wielu seminariów oraz wprowadzenia rekolekcji i konferencji dla księży ${ }^{11}$.

\footnotetext{
${ }^{5}$ L. M e z z a d r i, dz. cyt., s. 97-108.

${ }^{6}$ SVP XI, 6, Kraków 2017.

${ }^{7}$ L. M e z z a d r i, dz. cyt., s. 144.

${ }^{8}$ SVP XII, 259, dz. cyt.

9 M. P. Flore s, Spowiedź, [w:] Słownik Duchowości Wincentyńskiej t. 2, Kraków 2010, s. 281.

${ }^{10}$ J. D u k a ł a, Szkoła księży misjonarzy, [w:] Dzieje teologii katolickiej w Polsce. t. 2 Od odrodzenia do Oświecenia, cz. 2. Teologia neoscholastyczna i jej rozwój $w$ akademiach i szkołach zakonnych, Lublin 1975, s. 106.

${ }^{11}$ L. N u o v o, Kapłaństwo, [w:] Stownik Duchowości Wincentyńskiej t. 1, Kraków 1997, s. 369.
} 
Bardzo dużym powodzeniem cieszyły się tzw. konferencje wtorkowe, które zrzeszały duchownych chcących żyć przykładnie. Ta propozycja była dla kapłanów swoistym wsparciem w codzienności i propozycją formacji ciągłej ${ }^{12}$.

W 1635 r w Paryżu, w kolegium Des Bons Enfants, Wincenty a Paulo po raz pierwszy dokonał próby założenia seminarium. Zgromadził kilku chłopców od dwunastego do czternastego roku życia. Niestety była to próba niedana. Najprawdopodobniej wynikało to ze zbyt młodego wieku kandydatów ${ }^{13}$. Druga próba założenia seminarium w Annecy w 1641, również skończyła się niepowodzeniem. Badacze dopatrują się tutaj porażki w zbyt dużej rozpiętości wieku kandydatów. W seminarium byli zarówno bardzo młodzi chłopcy, jak i starsi od nich młodzieńcy. Wincenty nie zraził się tymi porażkami i już rok później, w 1642 roku podzielił seminarzystów na dwie grupy wiekowe, starszych i młodszych. Dzięki wprowadzeniu takiego podziału powstało seminarium wyższe oraz został położony grunt pod małe seminaria ${ }^{14}$. Jak podaje ks. Wacław Umiński ${ }^{15}$, to właśnie św. Wincenty a Paulo uznawany jest za jednego z inicjatorów małych seminariów nazywanych też szkołami apostolskimi. Z czasem ta forma przyjęła się w wielu krajach, a zakładali je liczni biskupi oraz zakony i zgromadzenia.

\section{Małe seminarium w Polsce}

W Polsce małe seminaria prowadzone przez Zgromadzenie Misji powstały dopiero na początku XIX wieku. Pierwsze w prowincji litewskiej w 1808 roku, kolejne w prowincji krakowskiej w 1878 roku. W niniejszym opracowaniu chciałbym zająć się małym seminarium prowincji krakowskiej. W 1896 roku małe seminarium przeniesiono z centralnego domu w Krakowie przy ul. św. Filipa do misjonarskiego domu na Nowej Wsi (obecnie ul. Misjonarska, Kraków). Mieściło się w tym miejscu do 1952 roku z dwoma przerwami: pierwszą na czas pierwszej wojny światowej (lata 1914-1915) ${ }^{16}$; drugą na czas drugiej

\footnotetext{
12 J. M. R o m a n, Święty Wincenty a Paulo - Biografia, Kraków 1990, s. 435-436.

13 Por. SVP II, 259n; SVP I, 113.

${ }^{14}$ J. D u k a ł a, Szkoła księży misjonarzy, dz. cyt., s. 107.

15 W. U m i ń s k i, Polska prowincja Zgromadzenia Księży misjonarzy w latach 1918 1939, Kraków 2009, s. 167.

${ }^{16}$ F. B i m a, Osiemdziesiat lat..., „Meteor” nr 3; maj-czerwiec 1959, s. 115.
} 
wojny światowej w latach 1939-1945 ${ }^{17}$. Małe seminarium powróciło na Kleparz przy ul. św. Filipa w roku 1957. Ostatecznie zostało zamknięte w roku $1962^{18}$.

Kodeks prawa kanonicznego z 1917 roku określał ogólne zadania małych seminariów, które stały się instytucjami czysto kościelnymi, o charakterze szkół wyznaniowych i prywatnych ${ }^{19}$. W czasie drugiej wojny światowej wiele małych seminariów przestało istnieć. Duża część nie wznowiła swojej działalności po wojnie. Spowodowane to było wieloma względami. W pierwszych latach po wojnie wydawało się, że nowa władza, narzucona przez totalitarny system będzie tolerowała działalność małych seminariów. Tak też było, do 1948 r. kiedy to możliwe było nawiązywanie do tradycji przedwojennej i akceptowane było prawo dotyczące interesujących nas szkół ${ }^{20}$. Zgodnie z czasowo obowiązującym prawem, szkoły prowadzone przez jednostki kościelne, reaktywowane po wojnie, mogły działać na podstawie przepisów przedwojennych. Wyjątkiem były szkoły, które miały zostać założone jako nowe, czyli niebędące kontynuacją działalności przedwojennej. Te już były zależne i podległe ówczesnym władzom oświatowym ${ }^{21}$. Małe seminarium księży misjonarzy rozpoczęło swą działalność na nowo w roku 1946. Dyrektorem został ks. Hieronim Śmidoda $\mathrm{CM}^{22}$, który kontynuował swą funkcję po przerwie wojennej ${ }^{23}$. Pełnił ten urząd w niełatwym czasie, bo już od 1949 roku zaczęły pojawiać się głosy, by zastosować w stosunku do małych seminariów przepisy ustawy z 1932 roku $^{24}$. Duża zmiana podejścia do niższych seminariów widoczna jest po umocnieniu pozycji władzy komunistycznej. Chciano podporządkować całe szkolnictwo wyznaniowe kontroli państwa, także niższe i wyższe seminaria duchowne. Rozpoczęto cenzurowanie

\footnotetext{
${ }^{17}$ Misjonarze św. Wincentego a Paulo w Polsce (1651-2001); I - Dzieje, red. S. R o s p o n d, Kraków 2001, s. 457.

18 Por. AMS, sygn. VII.4/1/3, [F. B i m a], Struktura organizacyjno-wykonawcza Małego Seminarium.

${ }^{19}$ Por. Codex Iuris Canonici, Vatican 1974, can. 1364, 1369.

${ }^{20}$ Por. art. 113 i 114 Konstytucji marcowej z 1921 r. art. XIII Konkordatu z 1925 r.

${ }_{21}$ Por. S. B o b e r, Walka o dusze dzieci i młodzieży $w$ pierwszym dwudziestoleciu Polski Ludowej, Lublin 2011, s. 64, 348.

${ }^{22}$ Misjonarze św. Wincentego a Paulo w Polsce (1651-2001); dz. cyt., s. 402.

${ }^{23}$ Wcześniej był dyrektorem w latach 1930-1939.

${ }^{24}$ Ustawa z dnia 11 marca 1932 r. o prywatnych szkołach oraz zakładach naukowych $i$ wychowawczych (Dz. U. 1932 nr 33 poz. 343).
} 
i oczyszczanie bibliotek, przeprowadzano liczne i uciążliwe kontrole i wizytacje. Znane były przypadki inwigilowania wspólnoty seminaryjnej. Dla Urzędu Bezpieczeństwa małe seminaria były: „wylęgarnią dywersji politycznej, wrogiej propagandy i bandytyzmu" ${ }^{25}$. Problemy funkcjonowania seminariów były przedmiotem rozmów Komisji Mieszanej Rządu i Episkopatu w dniu 20 marca 1950 roku $^{26}$.

Te powojenne starania władzy socjalistycznej skierowane na zamknięcie małych seminariów nie ominęły także małego seminarium księży misjonarzy. W województwie krakowskim w 1951 roku łącznie działało 36 wyższych i niższych seminariów oraz nowicjatów. 3 lipca przeprowadzono akcję mającą na celu zamknięcie małych seminariów. Zamknięto 14 placówek wśród których były placówki należące do bernardynów, cystersów, jezuitów, karmelitów bosych, michalitów, misjonarzy, paulinów, pallotynów, pijarów, reformatów, salezjanów, salwatorianów, sercanów oraz zmartwychwstańców. Oficjalnym powodem był brak rejestracji w Wydziałach Oświaty Prezydium Rad Narodowych ${ }^{27}$. Małe Seminarium Zgromadzeni Misji zostało zlikwidowane na podstawie decyzji Prezydium Wojewódzkiej Rady Narodowej z dnia 30 czerwca 1952 roku. W archiwum zachował się tekst w/w decyzji, w którym czytamy, że „na podstawie art. 1, 2 i 3 ustawy z dnia 11 marca 1932 roku o prywatnych szkołach oraz zakładach naukowych i wychowawczych (Dz. U. R. P. Nr 33, poz. 343) oraz §2 rozporządzenia Ministra Wyznań Religijnych i Oświecenia Publicznego z dnia 7 czerwca 1932 r. (Dz. U. R. P. 50, poz. 473, z późniejszymi zmianami). Prezydium Wojewódzkiej Rady Narodowej w Krakowie zarządza niezwłoczne zamknięcie Małego Seminarium ks. Misjonarzy w Krakowie ulica Misjonarska 37"28. Taka decyzja była uzasadniona brakiem orzeczenia o dalszej działalności szkoły wydanego przez właściwe organa oświatowe. Decyzja ta została do-

\footnotetext{
25 J. P i etrzy k ow s k i, Likwidacja Matych Seminariów Duchownych w Polsce prowadzonych przez Towarzystwo św. Franciszka Salezego, [w:] „Roczniki Teologiczne", t. LXI, zeszyt 4 - 2014, s. 208.

26 Tamże, s. 208-209.

27 J. M a r e c k i, Kościót w okowach; Zakony pod presja bezpieki; Aparat bezpieczeństwa wobec wspólnot zakonnych na terenie województwa krakowskiego 1944-1975, Kraków 2009, s. 492.

28 AMS, sygn. VII.4/III/3, Korespondencja, Pisma do Niższego Seminarium z lat 19061965, Wojewódzka Rada Narodowa w Krakowie, pismo z 30 VI 1952, [s. 1].
} 
starczona 3 lipca 1952 roku o godzinie 10 przez funkcjonariuszy Wojewódzkiej Rady Narodowej. Zakazali oni opuszczania domu oraz oświadczyli, że część domu zajmowana przez małe seminarium, całe wyposażenie oraz ogród przechodzą na własność państwa ${ }^{29}$. W związku z tą decyzją ówczesny Wizytator Polskiej Prowincji Księży Misjonarzy ${ }^{30}$ ks. Józef Kryska odwołał się do odpowiednich władz powołując się m.in. na Konstytucję RP z 17 marca 1921 oraz konkordat z 1925 roku. W swych pismach ukazywał potrzebę stworzenia takiej szkoły, w której w szczególności będzie kładziony nacisk na wysoki poziom kształcenia oraz fakt nierozerwalności ze zgromadzeniem $^{31}$. Niestety odwołanie nie przyniosło oczekiwanych skutków, seminarium zostało zlikwidowane, a budynek przekazany na potrzeby Akademii Medycznej i powstał w nim szpital ${ }^{32}$.

Czas przerwy w funkcjonowaniu małego seminarium trwał aż do 1957 roku. Na prośbę wyższych przełożonych zakonnych skierowaną do posła Stanisława Stommy, na postawie pisma ministra Jerzego Sztachelskiego z 5 kwietnia umożliwiono na nowo działalność małych seminariów. Niestety kwestię zwrotu zabranych budynków pozostawiono w gestii poszczególnych Prezydiów Rad Narodowych ${ }^{33}$. Potwierdzenie tej decyzji przez Prezydium Miejskiej Rady Narodowej - Wydział ds. Wyznań w Krakowie, Zgromadzenie Księży Misjonarzy uzyskało 24 maja 1957 roku $^{34}$. Udało się także odzyskać część dokumentów zabranych podczas likwidacji małego seminarium ${ }^{35}$.

Okres działalności małego seminarium Zgromadzenia Księży Misjonarzy trwał tylko 5 lat, do momentu, kiedy to 28 czerwca 1962 roku przysłano pismo z Kuratorium Szkolnego w Krakowie, w którym poinfor-

29 AMS, sygn. VII.4/III/4, Korespondencja, Pisma dyrekcji seminarium 1926-1965, 1952, 8 VII nr 5, [s. 1].

${ }^{30}$ Wizytator - w Zgromadzeniu Księży Misjonarzy, w taki sposób tradycyjnie określa się Prowincjała.

31 AMS sygn. VII.4/III/4, Korespondencja, Pisma dyrekcji seminarium 1926-1965, 1952, 8 VII nr 4, [s. 2-5].

32 J. M a r e c k i, Kościól w okowach; dz. cyt., s. 509-510.

33 AMS, sygn. VII.4/III/3, Korespondencja, Pisma do Niższego Seminarium z lat 19061965, 1957, nr 3.

34 AMS, sygn. VII.4/III/4, Korespondencja, Pisma dyrekcji seminarium 1926-1965, $1957, \mathrm{nr} 2$.

35 AMS, sygn. VII.4/III/4, Korespondencja, Pisma dyrekcji seminarium 1926-1965, 1958, 8 VII nr 1-2. 
mowano o chęci wystąpienia o nieudzielenie zezwolenia na dalsze istnienie szkoły. Swoją decyzję motywowano w bardzo niezrozumiały sposób, stwierdzając, że podczas wizytacji zauważono ,niewłaściwe stosunki wychowawcze wywierające specyficzny wpływ na charakter i psychikę młodzieży, co jest szczególnie szkodliwe dla licznych alumnów opuszczających Seminarium"36. Tydzień później, 5 lipca, misjonarze złożyli obszerne wyjaśnienia, uznając podane argumenty za niesłuszne i krzywdzące. Pismo wymienia, że w czasie wizytacji przeprowadzonej w dniach 1314 marca nie zostały zauważone żadne uchybienia ani niewłaściwe stosunki wychowawcze. Wskazano, że gdyby takie zaistniały należałoby, wg rozporządzenia ministra zdrowia, zgłosić je władzom seminarium. W uzasadnieniu powołano się także na fakt, że wiele osób prowadzących korespondencję $\mathrm{z}$ dyrekcją stwierdza, że nie ma żadnych problemów z przystosowaniem się do atmosfery panującej w szkołach państwo$w_{y c h}{ }^{37}$. Znów odwołanie od decyzji nie przyniosło zmiany postanowienia władz. Pismo o likwidacji Małego Seminarium Duchownego Księży Misjonarzy z dnia 23 lipca 1962 roku, przysłane przez Ministerstwo Oświaty spowodowało zamknięcie szkoły 26 lipca. Pismo nakazywało także oddanie wszystkich akt i pieczęci ${ }^{38}$ do dnia 31 sierpnia 1962 roku.

Opis ostatnich chwil funkcjonowania małego seminarium znajdziemy w archiwum. Ks. Franciszek Bima ${ }^{39}, 26$ lipca odczytał pismo z kuratorium mówiące o zamknięciu seminarium. Po zwróceniu uwagi na nieścisłości dotyczące liczby pomieszczeń księża misjonarze usłyszeli w odpowiedzi, że jest to nieważne, gdyż zostają zajęte wszystkie. Nie pomogły sprzeciwy ówczesnego Wizytatora Polskiej Prowincji Księży Misjonarzy ks. Aleksandra Usowicza CM. Eksmisja przebiegła szybko, gdyż wcześniej została przygotowana cała strona logistyczna. Nie patrzono na zniszczenia, w czasie wynoszenia wyposażenia pokoi. Działania trwały do godziny 23, a następnego dnia zakończono całą akcję o godzinie 15. Mimo, że kilkukrotnie odwoły-

\footnotetext{
${ }^{36}$ AMS, sygn. VII.4/III/3, Korespondencja, Pisma do Niższego Seminarium z lat 19061965, 1962, nr 1.

37 AMS, sygn. VII.4/III/4, Korespondencja, Pisma dyrekcji seminarium 1926-1965, 1962, nr 1.

38 AMS, sygn. VII.4/III/3, Korespondencja, Pisma do Niższego Seminarium z lat 19061965, 1962, nr 3.

${ }^{39}$ Ks. Franciszek Bima CM, ur. 3.12.1919 roku pełnił funkcję dyrektora placówki w latach 1957-1962. Por. AMS, Teczka personalna, Ks. Bima Franciszek, I/1-4.
} 
wano się od tej decyzji, nie przyniosło to pożądanego skutku. Był to ostateczny koniec małego seminarium Księży Misjonarzy ${ }^{40}$.

\section{Likwidacja malego seminarium - prawdziwe powody}

Jaki był powód likwidacji tej formy szkolnictwa? Warto zbadać, czy powodem nie był niski poziom nauczania, niedostosowanie wychodzących uczniów, brak odpowiednich warunków socjalnych i nieodpowiednia dbałość o wychowanków, czy też może brak przygotowania nauczycieli.

Postarajmy się zatem spojrzeć na te tematy i ich wypełnianie w małych seminariach, na przykładzie małego seminarium Zgromadzenia Księży Misjonarzy św. Wincentego a Paulo.

Małe seminaria miały nie tylko przekazać pewne wiadomości, ale były miejscem wychowania młodych chłopców, były: „Ogniskiem bezpośrednich przeżyć i związanych z charakterem Szkoły Apostolskiej potrzeb i zainteresowań uczęszczającej do niej młodzieży"41. Miały na celu odkryć i rozbudzić w młodzieńcach powołanie kapłańskie, odpowiednie charyzmatowi danego zgromadzenia. Celem małego seminarium było przygotowanie młodzieży do dalszej nauki na studiach uniwersyteckich lub filozoficzno-teologicznych w seminariach, a także wykształcenie chłopców w taki sposób, by byli świadomi swych obowiązków jako członkowie Kościoła, oraz obywatele państwa dzięki ukształtowaniu w nich osobowości religijnej, moralnej, społecznej, umysłowej i fizycznej ${ }^{42}$. Stąd małe seminaria miały charakter ogólnokształcący, a ich program był ustalany na podstawie programu szkoły ogólnokształcącej, na poziomie liceum. Kiedy spojrzymy na cele szczegółowe seminariów, zauważymy, że miały one pomóc uczniowi w:

1. przyswojeniu podstawowego zasobu wiadomości,

2. nabyciu niezbędnych w życiu umiejętności,

40 AMS, sygn. VII.4/III/3, Korespondencja, Pisma do Niższego Seminarium z lat 1906-1965, 1962/16, Likwidacja Niższego Seminarium - relacja Kleparz 1962, s. 2-6. 41 AMS, sygn. VII.4/I/3, Historia szkół, Struktura organizacyjno-wychowawcza Małego Seminarium, s. 3.

42 AMS, sygn. VII.4/II/3, Sprawy organizacyjne, Statut Niższego Seminarium Księży misjonarzy 1957. 
3. obudzeniu zamiłowania do rozwijania zdolności i dyspozycji umysłowych,

4. kształceniu charakteru i uczuć ${ }^{43}$.

Niższe seminarium funkcjonowało w specyficzny sposób, w porównaniu do innych typów szkół ogólnokształcących, ponieważ uczniowie, zwani alumnami przebywali w nim cały czas, często także w okresie świąt. Szkoła ta miała nie tylko kształcić pod względem naukowym, ale była też miejscem wychowania. Po lekcjach odbywały się spotkania oraz pogadanki dotyczące zasad poprawnego zachowania się. Przyjmowały różne formy, od wykładów poprzez rozmyślania czy rozmowy zarówno wspólnotowe jak i indywidualne. To powodowało, że nie musiała być przeprowadzana dodatkowa godzina wychowawcza, a jej czas przeznaczony był na dodatkową lekcję religii ${ }^{44}$.

Dyrektor małego seminarium Księży Misjonarzy, ks. Franciszek Bima, uważał, że nie powinno się pomijać żadnego z przedmiotów nauczanych w szkołach państwowych, gdyż będzie to ze szkodą dla uczniów. W jego opinii, po rozmowach i korespondencji z dyrektorami innych niższych seminariów, zdarzało się, że w innych seminariach były pomijane w szczególności: rysunek, przysposobienie wojskowe oraz gimnastyka ${ }^{45}$. Dyrektor placówki, ks. Bima uważał, że te przedmioty powodują aktywizację uczniów oraz rozbijają monotonię. Znając specyfikę działań w Zgromadzeniu Misji, mówił, że uczniowi potrzebna jest znajomość rysunku, z jednej strony, by mógł on rozwinąć zmysł estetyczny, a z drugiej, by był on kompetentny w przypadku kontaktów z budowniczymi, rzemieślnikami czy innymi fachowcami, na wypadek gdyby została powierzona absolwentowi szkoły opieka nad budową kościoła czy innego obiektu. W misjonarskim małym seminarium przywiązywano także dużą wagę do wychowania fizycznego, które wpływa nie tylko na budowę fizyczną, ale także na charakter rozwijającego się młodzieńca. Nie da się tych zajęć zastąpić przechadzkami, czy grami w czasie rekreacji. Jak czytamy w archiwach, zwracano uwagę, by gimnastyka nie czyniła z uczniów sportowców, ale sprawiała, by

\footnotetext{
43 AMS, sygn. VII.4/I/3, Historia szkół, Struktura organizacyjno-wychowawcza Małego Seminarium, s. 12.

44 Tamże, s. 6.

45 Tamże, s. 4.
} 
w przyszłości duchowny charakteryzował się odpowiednim zdrowiem i potrzebnymi możliwościami fizycznymi. W misjonarskiej placówce nie brakowało również zajęć z przysposobienia wojskowego, które miało wyrobić w młodzieży zapał, werwę, ochoczość do czynu oraz ufność w to, że jest potrzebna społeczeństwu ${ }^{46}$.

W małym seminarium Księży Misjonarzy, wymienione powyżej przedmioty uznawane były za równie ważne. Zarząd małego seminarium był przekonany, że całościowe podejście do ucznia ukształtuje z młodzieńca mężczyznę, który będzie dobrym obywatelem i chrześcijaninem.

Małe Seminarium Księży Misjonarzy realizowało program szkoły ogólnokształcącej, z kilku powodów. W archiwum, w zapisach przełożonych placówki, znajdujemy cztery argumenty:

1. Małe seminaria były szkołami ogólnokształcącymi na równi $\mathrm{z}$ liceami;

2. Ponieważ zdarzały się przypadki opuszczenia, z różnych powodów, szkoły przed jej końcem, uczeń powinien mieć możliwość dalszej edukacji w każdej innej szkole, także państwowej;

3. Uczniowie w czasie wakacji, ferii, przerw świątecznych spotykali się ze swoimi kolegami z innych szkół, także państwowych. Nie można było dopuścić, by były zauważalne braki w ich edukacji, co mogłoby spowodować kompleks niższości, rozczarowanie czy brak zaufania do szkoły;

4. Młodzież, która oddała się pod opiekę małego seminarium, nie powinna stać niżej pod względem naukowym i umysłowym niż inni. W szczególności dlatego, że była kształcona przez księży ${ }^{47}$.

Dużą wagę przykładano także do nauki języków obcych. Pierwszym z nich, była łacina, co jest zrozumiałe $z$ racji specyficznego charakteru szkoły i przygotowania przyszłych alumnów wyższych seminariów duchownych. Z języków nowożytnych uczniowie mieli do wyboru: angielski, francuski, niemiecki i rosyjski. Po wejściu w życie rozporządzenia $\mathrm{z}$ dnia 11 stycznia 1958 roku $^{48}$ obowiązkowym na

\footnotetext{
46 AMS, sygn. VII.4/I/3, Historia szkół, Struktura organizacyjno-wychowawcza Małego Seminarium, s. 4-5.

47 Tamże, s. 7-8.

${ }^{48}$ Dziennik Urzędowy Ministerstwa Oświaty, 1958 nr 6.
} 
egzaminie dojrzałości stał się język rosyjski. Stąd w małym seminarium wprowadzono trzeci język, który był nadobowiązkowym.

$\mathrm{Z}$ racji braku praw szkoły państwowej, egzaminy dojrzałości odbywały się eksternistycznie w innych szkołach. Wyniki maturalne pokazują, że poziom nauczania w małym seminarium był ponad przeciętny ${ }^{49}$.

W jednostkach oświatowych pojawiały się głosy o brakach w wyposażeniu szkół. Było w tym, trochę racji, bo placówka była dobrze zaopatrzona w pomoce naukowe, ale zostały one skonfiskowane w czasie pierwszej likwidacji w 1952 roku, kiedy to zabrano całe urządzenie internatu oraz szkoły ze wszystkimi pracowniami, także orkiestrą, muzeum i wyposażeniem sali gimnastycznej. Skonfiskowane zostały również wszystkie akta, katalogi i odpisy ${ }^{50}$. Zarząd placówki nie stał z założonymi rękoma, starał się sprostać problemom, które się pojawiły i zaczął doposażać sale, np. w pomoce naukowe ułatwiające uczniom przyswajanie wiedzy ${ }^{51}$.

Jednym $\mathrm{z}$ argumentów, który był podnoszony ku likwidacji małych seminariów było niskie wykształcenie i poziom nauczycieli. Takie krzywdzące zarzuty, bez kontroli i weryfikacji, przedstawiał Naczelnik Wydziału Departamentu Szkolnictwa Ogólnokształcącego Jan Grela w listopadzie 1956 roku. Twierdził on, że w małych seminariach uczą starzy emeryci i domorośli nauczyciele, którzy nie mając odpowiedniego przygotowania, a uczą po 5-6 przedmiotów. Dyrektor placówki, ks. Bima próbował odpierać te ataki, lecz okazało się to bezskuteczne ${ }^{52}$. To jeszcze bardziej utwierdziło zarząd seminarium, że należy zadbać o nauczycieli, którzy będą spełniali najwyższe wymagania, by jak najlepiej przygotowali małoseminarzystów do egzaminu dojrzałości. Chciano udowodnić egzaminatorom oraz władzom oświatowym, że szkoły prowadzone przez księży są przykładnymi placówkami ${ }^{53}$. Wielokrotnie podkreślano, że małe seminarium Księży Misjonarzy posia-

\footnotetext{
49 AMS, sygn. VII.4/I/3, Historia szkół, Struktura organizacyjno-wychowawcza Małego Seminarium, s. 6.

50 AMS, sygn. VII.4/III/5, Korespondencja, Akta i korespondencja Małego Seminarium oraz Gimnazjum na Nowej Wsi Królewskiej w Krakowie z lat 1878-1952.

51 AMS, sygn. VII.4/I/3, Historia szkół, Struktura organizacyjno-wychowawcza Małego Seminarium, s. 8.

52 Tamże, s. 8 .

53 Tamże, s. 10 .
} 
da bardzo dobrą kadrę nauczycielską ${ }^{54}$, która jest oddana także sprawie wychowania i nie wykonuje swej pracy jako przykrego obowiązku, który miałby jedynie na celu zdobycie comiesięcznego zarobku ${ }^{55}$. Istotny wpływ na pracę i jej poziom miała odpowiednia kontrola nauczycieli. Nierzadkie hospitacje, organizowanie konferencji pedagogicznych, troska o systematyczność prowadzenia dziennika lekcyjnego, dokładne harmonogramy rozplanowania czasu i treści na lekcji, były formami mającymi na celu mobilizację nauczyciela do jeszcze bardziej wytężonej i owocnej pracy. Zwracano często uwagę, by nie rozpraszać tematów lekcji, opowiadając historie niemające bezpośredniego związku $\mathrm{z}$ tokiem nauczania. Liczba dni nauki w małym seminarium była mniejsza niż w szkole państwowej, ponieważ brano pod uwagę święta kościelne (np. 8 grudnia, 2 lutego i inne) stąd tak ważna była dbałość o dobre wykorzystanie czasu lekcyjnego, o punktualne rozpoczynanie zajęć ${ }^{56}$.

Małe seminarium mogło poszczycić się całościowym podejściem do ucznia. Metody nauczania, harmonogram zajęć i odpowiednie rozłożenie materiału przyczyniało się do wzrostu poziomu nauki, a także prawidłowego rozwoju zdrowia umysłowego oraz fizycznego. Praca z uczniem była bardzo zindywidualizowana, brano pod uwagę jego zainteresowania, jego możliwości i zdolności psychiczne i fizyczne, a także dokonywano nieustannej modyfikacji podejścia do rozwijającego się młodzieńca. Plan ułożony był w sposób naprzemienny przedmioty łatwiejsze (rysunek, wychowanie fizyczne, przysposobienie wojskowe i śpiew), przemieniano ze średnio trudnymi (historia, biologia, geografia i religia) oraz $\mathrm{z}$ najtrudniejszymi (matematyka, fizyka, chemia i języki). Te ostatnie umieszczano na drugiej i trzeciej godzinie lekcyjnej, które uznawano za najbardziej wydajne pod względem przyjmowania nauki. Ważnym i pilnowanym aspektem były przerwy szkolne, w czasie których alumni korzystali z gier i zabaw

\footnotetext{
54 „Wychowawcę Szkoły Apostolskiej winna cechować umiejętność poznawania wychowanka i całej grupy. Winien posiadać zmysł obserwacji i znajomość psychiki młodzieży. Troska wychowawcy powinna obejmować ogół potrzeb alumna" - AMS, sygn. VII.4/I/3, Historia szkół, Struktura organizacyjno-wychowawcza Małego Seminarium, s. 27.

55 Tamże, s. 9.

56 AMS, sygn. VII.4/I/3, Historia szkół, Struktura organizacyjno-wychowawcza Małego Seminarium, s. 9-11.
} 
ruchowych. Ciekawe są spostrzeżenia wychowawcze, które ukazują różnice poziomu aktywności umysłowej ucznia. Czytamy, że po powrotach z niedzielnego odpoczynku oraz po świętach, uczniowie wykazywali niższy poziom pracy. We wtorki i środy poziom sprawności umysłowej był najwyższy, a spadek pojawiał się znów w czwartek i piątek. Sobota była także dniem wzrostu sprawności intelektualnej, gdyż uczniowie już czekali na niedzielną przerwę w nauce. Układając plan zajęć w małym seminarium, starano się brać pod uwagę wszystkie te czynniki ${ }^{57}$.

W opinii niektórych, małe seminaria nie przygotowywały młodych ludzi do funkcjonowania w społeczeństwie, że nie uczą zaradności i samodzielności, ale ograniczają myślowo wychowanków. Kiedy pojawiały się takie zarzuty, jak wielkie zdziwienie musiało ogarniać zarząd placówki, który często powtarzał, że nie chcą ograniczać samodzielności młodzieży i nie wychowywać „ludzi szablonu"58. W małym seminarium Księży Misjonarzy bardzo aktywnie działał samorząd uczniowski. W seminarium przebywali chłopcy z całej Polski, uczniowie z różnymi talentami, przywarami i wadami, ale także ogromnym potencjałem. Łączył ich wspólny cel, jakim było pragnienie kapłaństwa ${ }^{59}$.

Działalność samorządu szkolnego, była bardzo pomocna w całym procesie wychowania. Zaangażowanie w jego pracę uczyło współpracy, skłaniało do podejmowania odpowiedzialności za działania wspólnoty oraz za własne czyny, a także pobudzało do samokształcenia i rozwijania swoich talentów, by móc nimi służyć innym. Struktura samorządu uczniowskiego w małym seminarium Księży Misjonarzy jeszcze dziś budzi podziw. Pewną nowością była możliwość demokratycznego wyboru przedstawicieli na urzędy, co sprawiało, że młodzież ich bardziej słuchała i szanowała. Pokazuje to jak bardzo księżom misjonarzom zależało na całościowym rozwoju ucznia i przygotowaniu go do życia w społeczeństwie. Samorząd składał się z różnych działów:

1. dział samokształceniowy - organizował dyskusje, pogadanki, odczyty z różnych dziedzin, by poszerzyć wiedzę,

\footnotetext{
57 Tamże, s. 10-13.

58 Tamże, s. 14.

59 Tamże.
} 
2. dział czytelnictwa - zachęcał do czytania prasy i książek, a także redagował gazetkę ścienną,

3. dział techniczny, który skupiał uczniów posiadających talenty w dziedzinie elektrotechniki, kreślarskie, fotograficzne i inne,

4. dział artystyczny:
a. sekcja dekoratorska,
b. sekcja wokalno-muzyczna, m.in. działał w niej chór oraz or- kiestra dęta,
c. sekcja sceniczna,
d. sekcja wychowania fizycznego i turystyczna.,

5. sądy uczniowskie - dbały o porządek i dyscyplinę i mogły stosować sankcje, które jasno określał statut samorządu szkolnego ${ }^{60}$.

Kolejnym zarzutem pojawiający się przeciwko istnieniu małych seminarium był brak odpowiedniej opieki w czasie przebywania młodych osób w internacie. Kiedy czytamy dokumenty małego seminarium Księży Misjonarzy odsłania się przed nami ogromna troska o zdrowie i higienę życia alumnów. Jak już wcześniej podałem, plan zajęć był tak układany, by jak najlepiej wykorzystać kondycję intelektualną i fizyczną wychowanka. Dbano o odpowiednią ilość snu, właściwy czas odpoczynku, a także o regularne i odpowiednie do wieku odżywianie. Część z chłopców pochodziła z rodzin, w których nie dbano o higienę osobistą, stąd wielka troska wychowawców i opiekunów, by przyzwyczaić ich, a niektórych nawet nauczyć, takich czynności jak mycie rąk, uszu, szyi, twarzy, nóg czy zębów. Czas wieczornej ciszy także miał pomóc dobrej regeneracji sił w nocy. Dbano, by czas odrabiania pracy domowej nie przekraczał czterech godzin dziennie. Uważano, że po tym czasie zdolność przyswajania informacji przez ucznia zmniejsza się, a poziom wykonywanych zadań znacząco spada. Uczniowie mieli do dyspozycji salę „studium”, w której obowiązywał regulamin pomagający w skupieniu się na pracy, nazwany „przykazaniami pracy”61. W archiwach czytamy, że w całym seminarium stworzone były warunki spełniające wszystkie wytyczne i normy dotyczące higieny pracy, takie jak powierzchnia

\footnotetext{
${ }^{60}$ AMS, sygn. VII.4/I/3, Historia szkół, Struktura organizacyjno-wychowawcza Małego Seminarium, s. 17.

61 Tamże, s. 24.
} 
miejsca pracy, kubatury wdychanego powietrza, odpowiednie oświetlenie, temperatura itp. Uczniowie dbali o porządek w swoich pokojach i miejscach ogólnodostępnych. Zatrudniony był także personel świecki, który dbał o odpowiednie warunki i higienę. Małoseminarzyści nie byli służącymi, ale wychowankami. Zadania porządkowe miały pomóc w kształtowaniu młodzieńca, a nie być jego głównym zadaniem, ponieważ wtedy istniałoby ryzyko, że mógłby zaniedbywać inne sprawy. Chłopcy mieli także zapewnioną opiekę pielęgniarki, lekarza oraz stomatologa ${ }^{62}$. Wychowawcy w internacie byli bardzo dokładnie wybierani, mieli oni przewodzić wychowankom, rozszerzać ich horyzonty powołania, ożywiać zdobywaną w szkole wiedzę. Jak mówił ks. Bima, dyrektor placówki, bardzo ważne jest podejście indywidualne do każdego z wychowanków: „Nie możemy poprzestać na wychowaniu zbiorowym, masowym, gdyż każdy wychowanek to odrębny «świat»" 63 .

\section{Podsumowanie}

Kiedy ogłoszono decyzję o likwidacji małego seminarium, tłumacząc ją: „Niewłaściwe stosunki wychowawcze wywierające specyficzny wpływ na charakter i psychikę młodzieży, co jest szczególnie szkodliwe dla licznych alumnów opuszczających Seminarium"64, zarząd placówki przedstawił szereg argumentów mówiących o tym, że ta decyzja jest niesłuszna. Z powyższego artykułu i opisu działalności małego seminarium, możemy jasno wywnioskować, że władzom socjalistycznym nie chodziło o poziom nauczania czy wychowania, ani też o rzekome zaniedbania wynikające z prowadzenia tej szkoły przez Zgromadzenie Księży Misjonarzy św. Wincentego a Paulo. Powód był zupełnie inny. Małe seminaria były nie po myśli rządzących państwem. Chcieli oni mieć bezwzględną kontrolę nad wszystkimi dziedzinami życia swoich obywateli, a w szczególności nad szkolnictwem. Małe seminaria stały się tworami, które nie podlegały władzy państwa, ponieważ albo z niej zrezygnowały z niej albo powstały bez jej aprobaty. Małe seminaria

\footnotetext{
62 Tamże, s. 19-25.
}

${ }^{63}$ AMS, sygn. VII.4/I/3, Historia szkół, Struktura organizacyjno-wychowawcza Małego Seminarium, s. 28.

${ }^{64}$ AMS, sygn. VII.4/III/3, Korespondencja, Pisma do Niższego Seminarium z lat 19061965, 1962, nr 1 . 
były zwolnione z przygotowywania jakichkolwiek sprawozdań, planów, programów, rozdziałów czynności. Młodzież z małego seminarium nie musiała brać udziału w społecznych imprezach masowych takich jak: biegi narodowe, pochody, rocznice, prace przy odśnieżaniu ulic, porządki, troska o planty, skwery, rabaty. W seminariach uczono prawdziwej historii, a nie tej, którą propagowały władze komunistyczne. Jak widzimy w powyższym tekście, kilkakrotnie chciano uporać się ze szkołami prowadzonymi przez podmioty kościelne. Artur Mezglewski w swoim artykule ${ }^{65}$ zastanawia się nad legalnością likwidacji niższych seminariów. Wskazuje on, że pierwszym krokiem prowadzącym do likwidacji było przejście małych seminariów pod ustawę o prywatnych szkołach. Zgodnie z obowiązującymi przepisami minister oświaty mógł dokonać zamknięcia podległych sobie zakładów, gdy:

1. szkoła była nieczynna przez 3 miesiące bez usprawiedliwienia,

2. jej poziom naukowy lub wychowawczy w ciągu ostatnich trzech lat był niewystarczający,

3. nie przestrzegała obowiązujących przepisów lub postanowień statutu szkoły,

4. nauczanie lub wychowanie młodzieży odbywało się w duchu nielojalnym dla państwa, względnie szkoła nie przeciwdziałała skutecznie szkodliwym pod względem wychowawczym wpływom na młodzież ${ }^{66}$.

Według prawa likwidacji szkoły mógł dokonać tylko jej właściciel, bądź - w przypadku niedostosowania się właściciela do decyzji ministerstwa - organ egzekucyjny. Jednak rzeczywistość była inna, faktycznej likwidacji dokonywały terenowe władze oświatowe i wyznaniowe, zajmując także lokale po zlikwidowanych zakładach. Zamiar zamknięcia, zgodnie $\mathrm{z}$ obowiązującymi przepisami, powinien być zakomunikowany właścicielowi z odpowiednim wyprzedzeniem. Kiedy patrzymy na likwidację w roku 1952 i w roku 1962 widzimy znaczną różnicę, gdyż w tym pierwszym dokonano jej z zaskoczenia, bez uprzednich informacji, natomiast w 1962 roku informacja została wysłana z podanym uzasadnieniem, które tak naprawdę nie miało nic

65 A. M e z g l e w s k i, Proces likwidacji niższych seminariów duchownych w latach 1959-1963, „Studia z Prawa Wyznaniowego”, t. IV - 2002, s. 32-57.

${ }^{66}$ Dz. U. 1932 nr 33 poz. 343, art. 4, ust. 1. 
wspólnego z rzeczywistością. Zostały złożone obszerne wyjaśnienia. Tak jak do wszystkich innych niższych seminariów, po upływie 14 dni przychodziła decyzja o zamknięciu zakładu, z przypisem, że „wyjaśnienia, złożone na skutek uprzedzenia, podanego do wiadomości (...) uznaje się za niewystarczające"67.

Jasno widać, że sprawa zamknięcia Niższego Seminarium nie była podyktowana dobrem dzieci i młodzieży, ale była decyzją czysto polityczną. Niech podsumowaniem tego artykułu będą słowa Zenona Kliszki, najbliższego współpracownika Władysława Gomułki, który w czasie posiedzenia Komisji Komitetu Centralnego PZPR ds. Kleru powiedział: „Problem zeświecczenia NSD wiąże się przede wszystkim z koniecznością ograniczenia naboru do Wyższych Seminariów Duchownych prowadzonych przez zakony. Dlatego zainteresowani jesteśmy przede wszystkim w zeświecczeniu NSD zakonnych. W najbliższym czasie należy rozpracować sprawę ograniczenia działalności Wyższych Seminariów Duchownych prowadzonych przez zakony. Dotychczas nie zajmowaliśmy się tym problemy, a jest on ważny, gdyż ilość księży zakonnych stale wzrasta, co jest zjawiskiem niekorzystnym"

\section{Bibliografia}

\section{Źródła archiwalne}

Archiwum Polskiej Prowincji Zgromadzenia Księży Misjonarzy w Krakowie (AMS)

Zespół: Małe Seminarium Zgromadzenia Księży Misjonarzy

sygn. VII.4/I, Historia szkół

sygn. VII.4/II, Sprawy organizacyjne

sygn. VII.4/III/3, Korespondencja, Pisma do Niższego Seminarium z lat 1906-1965 sygn. VII.4/III/4, Korespondencja, Pisma dyrekcji seminarium 1926-1965

sygn. VII.4/III/5, Korespondencja, Akta i korespondencja Małego Seminarium

oraz Gimnazjum na Nowej Wsi Królewskiej w Krakowie z lat 1878-1952

${ }^{67}$ A. M e z g l e w s k i, $d z$. cyt. s. 50.

68 J. Ż u r e k, Kasata Placówek Wychowawczych, „Nasza Przeszłość” nr 102, s. 229. 


\section{Źródła drukowane}

Codex Iuris Canonici, Vatican 1974

Conc. Trid., sess. XXIII

Ustawa z dnia 11 marca 1932 r. o prywatnych szkołach oraz zakladach naukowych $i$ wychowawczych, Dz. U. $1932 \mathrm{nr} 33$ poz. 343

Dziennik Urzędowy Ministerstwa Oświaty. $1958 \mathrm{nr} 6$

\section{Opracowania}

Bima F., Osiemdziesiat lat..., „Meteor” nr 3; maj-czerwiec 1959, s.

Bober S., Walka o dusze dzieci i młodzieży w pierwszym dwudziestoleciu Polski Ludowej, Lublin 2011.

Dukała J., Szkoła księży misjonarzy, [w:] Dzieje teologii katolickiej w Polsce. t. 2 Od odrodzenia do Oświecenia, cz. 2. Teologia neoscholastyczna i jej rozwój w akademiach i szkołach zakonnych, Lublin 1975, s.

Flores M. P., Spowiedź, [w:] Słownik Duchowości Wincentyńskiej t. 2, Kraków 2010, s. 281.

Marecki J., Kościót w okowach; Zakony pod presja bezpieki; Aparat bezpieczeństwa wobec wspólnot zakonnych na terenie województwa krakowskiego 1944-1975, Kraków 2009.

Mezglewski A., Proces likwidacji niższych seminariów duchownych w latach 1959-1963, „Studia z Prawa Wyznaniowego”, t. IV - 2002, s.

Mezzadri L., Wincenty a Paulo, miłosierdzie i świętość, Kraków 2010.

Misjonarze św. Wincentego a Paulo w Polsce (1651-2001); I - Dzieje, red. S. Rospond, Kraków 2001.

Nuovo L., Kapłaństwo, [w:] Słownik Duchowości Wincentyńskiej t. 1, Kraków 1997.

Pietrzykowski J., Likwidacja Małych Seminariów Duchownych w Polsce prowadzonych przez Towarzystwo św. Franciszka Salezego, „Roczniki Teologiczne", t. LXI, zeszyt 4 - 2014, s.

Roman J. M., Święty Wincenty a Paulo - Biografia, Kraków 1990.

Umiński W., Polska prowincja Zgromadzenia Księży misjonarzy $w$ latach 1918-1939, Kraków 2009

Żurek J., Kasata Placówek Wychowawczych, „Nasza Przeszłość” t. 102 


\section{JACEK PIOTROWSKI CM}

\section{ZAMKNIĘCIE MALEGO SEMINARIUM W KRAKOWIE PROWADZONEGO PRZEZ KSIĘŻY MISJONARZY ŚW. WINCENTEGO A PAULO W LATACH 1945-1962}

Streszczenie: Autor w powyższym artykule, na przykładzie małego seminarium Księży Misjonarzy w Krakowie, stara się przybliżyć czytelnikowi tematykę niższych seminariów. Zwraca uwagę na kontekst historyczny oraz społeczny istnienia tych placówek. Ukazuje, jaki wpływ na kształtowanie młodego człowieka miały takie szkoły i jak przebiegał w nich proces wychowania. Autor przedstawia, jak po drugiej wojnie światowej zmieniło się podejście władzy państwowej do szkół prowadzonych przez podmioty kościelne. W opracowaniu, autor stara się znaleźć prawdziwe powody likwidacji niższych seminariów w Polsce, ukazując, że sprawa ich zamknięcia nie była podyktowana dobrem dzieci, ale była decyzją czysto polityczną.

Słowa kluczowe: Niższe seminarium, szkolnictwo, wychowanie, misjonarze.

\section{THE CLOSURE OF THE MINOR SEMINARY IN CRACOW RUN BY VINCENTIAN FATHERS IN 1945-1962}

Summary: The author of the article deals with minor seminaries on the basis of the minor seminary run by Vincentian fathers in Cracow. He pays attention to the historical and social context of these institutions. He shows the influence of these schools on young people and the education process. The author shows that after WWII the approach of Polish authorities towards the Catholic Church changed. He tries to find true reasons for dismantling minor seminaries in Poland. The closure was not driven by the good of the children, but by purely political factors.

Keywords: Minor seminary, school system, education, Vincentians. 
